\title{
Urotensin II contributes to the formation of lung adenocarcinoma inflammatory microenvironment through the NF-кB pathway in tumor-bearing nude mice
}

\author{
CHENG-HUA ZHOU $^{1 *}$, YA-YA WAN $^{1 *}$, XIANG-HUA CHU $^{2}$, ZHENG SONG $^{1}$, \\ SHU-HUA XING ${ }^{1}$, YU-QING WU ${ }^{3}$ and XIAO-XING YIN ${ }^{1}$ \\ ${ }^{1}$ School of Pharmacy, Xuzhou Medical College, Xuzhou, Jiangsu 221004; ${ }^{2}$ Pharmacy Department, \\ Affiliated Hospital of Qingdao University Medical College, Huangdao branch, Qingdao, Shandong 266500; \\ ${ }^{3}$ Department of Anesthetic Pharmacology, Xuzhou Medical College, Xuzhou, Jiangsu 221004, P.R. China
}

Received May 22, 2012; Accepted September 4, 2012

DOI: $10.3892 / \mathrm{ol} .2012 .932$

\begin{abstract}
Urotensin II (UII), a somatostatin-like cyclic peptide, was originally isolated from the fish urophysis. Our previous study showed that UII stimulates the proliferation of A549 lung adenocarcinoma cells and promotes tumor growth in a nude mouse xenograft model, suggesting that UII may contribute to the pathogenesis of lung adenocarcinoma. In this study, the underlying mechanism for UII to promote lung adenocarcinoma growth was explored by observing the effect of UII on the tumor inflammatory microenvironment in tumor-bearing nude mice. Immunohistochemical analysis showed that UII promoted the infiltration of $\mathrm{CD} 68^{+}$ tumor-associated macrophages (TAMs) in the tumor microenvironment. Enzyme-linked immunosorbent assay (ELISA) demonstrated that UII promoted the release of interleukin- 6 (IL-6), tumor necrosis factor- $\alpha$ (TNF- $\alpha$ ) and matrix metalloproteinase-9 (MMP-9). Western blot analysis showed that UII promoted the activation of nuclear factor- $\mathrm{KB}(\mathrm{NF}-\mathrm{\kappa} \mathrm{B})$. These findings suggest that the enhanced levels of IL-6, TNF- $\alpha$ and MMP-9 in the tumor microenvironment, which likely resulted from increased activation of NF- $\mathrm{kB}$ induced by UII, may be one of the important mechanisms by which UII promotes lung adenocarcinoma growth. These findings imply that antagonists of UII or urotensin II-receptor (UT-R) have potential for the prevention and treatment of lung adenocarcinoma.
\end{abstract}

Correspondence to: Dr Xiao-Xing Yin, School of Pharmacy, Xuzhou Medical College, 209 Tongshan Road, Xuzhou, Jiangsu 221004, P.R. China

E-mail: yinxxgood@126.com

*Contributed equally

Key words: urotensin II, lung adenocarcinoma, inflammatory microenvironment, nude mice

\section{Introduction}

Several lines of evidence have suggested a strong association between chronic inflammation and carcinogenesis (1-4). It has been estimated that up to $20 \%$ of all tumors arise from the sites of infection, chronic irritation and inflammation (1). Persistent stimulation of chronic inflammation may cause the infiltration of inflammatory cells, the release of cytokines and the production of reactive oxygen species, which results in DNA damage, angiogenesis, tumor invasion and metastasis (1). There are numerous types of inflammatory cells in the tumor microenvironment, and tumor-associated macrophages (TAMs) are a major component. While the role of TAMs in tumor development is complex and multifaceted, in clinical studies, increased TAM density has been found to be associated with poor prognosis (5-7). TAMs contribute to tumor development through several mechanisms, including releasing angiogenic factors, promoting tumor cell proliferation, and facilitating tumor cell invasion and metastasis (8).

Lung cancer is one of the models of inflammation-driven carcinogenesis $(9,10)$. It has been shown that chronic exposure to tobacco smoke is the major risk factor for development of lung cancer by inducing inflammation $(11,12)$. Takahashi et al (13) further demonstrated that tobacco smoke promotes lung tumorigenesis by triggering IKK $\beta$ - and JNK1-dependent inflammation. Moreover, regular use of nonsteroidal antiinflammatory drugs decreases the risk of lung cancer $(14,15)$. Therefore, inflammation plays an important role in lung carcinogenesis.

Urotensin II (UII), a somatostatin-like cyclic peptide, was originally isolated from the fish urophysis (16). Subsequently, the cDNAs encoding UII in a human (17), monkey (18), mouse and rat (19) were cloned. It has been demonstrated that UII is an endogenous ligand for the orphan G-protein-coupled receptor (GRP14) (20), which is now known as urotensin II receptor (UT-R) (21). Recent studies suggest that UII is involved in the inflammatory reaction $(22,23)$. In cardiomyocytes, UII has been shown to stimulate interleukin-6 (IL-6) release through UT-R (22). A study by Segain et al (23) demonstrates that UII is a new chemotactic factor for 
UT-R-expressing monocytes. UII has also been shown to induce cellular adhesion molecule expression in human coronary endothelial cells (24). On the other hand, inflammatory cells and cytokines also regulate the release and expression of UII and UT-R. It has been demonstrated that lymphocytes are by far the largest producers of UII, while monocytes and macrophages are the largest producers of UT-R (25). In the human rhabdomyosarcoma cell line TE-671, the expression of UT-R has been shown to be upregulated by interferongamma (26). In addition, stimulation of monocytes with lipopolysaccharide (LPS), IL- $1 \beta$ and tumor necrosis factor- $\alpha$ (TNF- $\alpha$ ) upregulates UT-R expression (23).

Our previous study demonstrated that UII stimulated the proliferation of lung adenocarcinoma A549 cells and promoted lung adenocarcinoma growth in a nude mice xenograft model (27), suggesting that UII may contribute to the pathogenesis of lung adenocarcinoma. However, further study is needed to explore the underlying mechanism of UII in lung adenocarcinoma. Since lung carcinogenesis is associated with chronic inflammation, and UII is involved in certain inflammatory reactions, we considered whether UII could promote lung carcinogenesis through modulating the inflammatory microenvironment. Therefore, in the present study, we observed the effect of UII on the inflammatory microenvironment of lung adenocarcinoma in tumor-bearing nude mice.

\section{Materials and methods}

Materials. Human UII was obtained from Sigma Chemical Co. (St. Louis, MO, USA). Antibody for phosphorylated-nuclear factor- $\kappa \mathrm{B}(\mathrm{p}-\mathrm{NF}-\kappa \mathrm{B})$ was obtained from Bioworld Technology (Minneapolis, MN, USA). Antibodies for CD68 and NF- $\kappa \mathrm{B}$ were purchased from Biosynthesis Biotechnology Co., Ltd. (Beijing, China). Mouse IL-6 enzyme-linked immunosorbent assay (ELISA) kits, mouse TNF- $\alpha$ ELISA kits, mouse matrix metalloproteinase-9 (MMP-9) ELISA kits and horseradish peroxidase-coupled goat anti-rabbit IgG were purchased from Boster Biological Technology, Ltd. (Wuhan, China). BCA Protein Assay kit was obtained from Pierce Co. (Rockford, IL, USA). The study was approved by the ethics committee of Xuzhou Medical College, Xuzhou, China.

Cell culture and tumor-bearing nude mice model. The cell culture process and establishment of the tumor-bearing nude mice model were described in our previous study (27).

Immunohistochemistry for CD68 expression. The tumor tissues were embedded in optimal cutting temperature (OCT) compound and fresh-frozen with liquid nitrogen. The tissues were sectioned at a thickness of $10 \mu \mathrm{m}$. For immunohistochemistry, the frozen sections were immersed for $10 \mathrm{~min}$ in $0.5 \%$ hydrogen peroxide to deplete endogenous peroxidase activity. Following pre-incubation with $5 \%$ bovine serum albumin for $30 \mathrm{~min}$ to prevent nonspecific staining, the sections were incubated with rabbit anti-mouse CD68 antibody $(1: 200)$ at $4^{\circ} \mathrm{C}$ overnight. The sections were then incubated with horseradish peroxidase-coupled goat anti-rabbit IgG antibody for $20 \mathrm{~min}$, followed by incubation with strep-avidin-biotin-peroxidase complex $(\mathrm{SABC})$ for $20 \mathrm{~min}$ at $37^{\circ} \mathrm{C}$. The peroxidase was visu- alized by incubation with 3, 3'-diaminobenzidine (DAB) in the dark for $3 \mathrm{~min}$. The sections were counterstained with hematoxylin, dehydrated, and observed under a light microscope. Negative controls were established using PBS as a substitute for CD68 antibody. Positive staining was indicated by brown deposits.

ELISA analysis for the protein levels of IL-6, TNF- $\alpha$ and MMP-9. The tumor tissues were homogenized in lysis buffer (RIPA) containing phenylmethanesulfonyl fluoride (PMSF) at $4^{\circ} \mathrm{C}$. Homogenates were centrifuged at $12,000 \mathrm{x} \mathrm{g}$ for $15 \mathrm{~min}$ at $4^{\circ} \mathrm{C}$, and supernatant fractions were used for ELISA analysis. Next, $100 \mu \mathrm{l}$ sample or standard was added to each well of 96-well plates coated with primary antibody. The plates were incubated at $37^{\circ} \mathrm{C}$ for $90 \mathrm{~min}$ and then washed five times. Biotinylated specific antibody was added into each well and incubated at $37^{\circ} \mathrm{C}$ for $60 \mathrm{~min}$. Plates were then washed, incubated with $100 \mu \mathrm{l}$ diluted streptavidin-HRP at $37^{\circ} \mathrm{C}$ for $30 \mathrm{~min}$. Following washing, the color was produced by addition of $100 \mu \mathrm{l}$ substrate solution for $25 \mathrm{~min}$. Finally, $100 \mu \mathrm{l}$ stop solution was added to terminate the reaction.

Western blot analysis for $p-N F-\kappa B$. The lysis supernatants were used for western blot analysis. Protein concentrations were determined by a BCA Protein Assay kit. The protein sample was separated on a $12 \%$ SDS-polyacrylamide gel and transferred onto a nitrocellulose membrane by electrotransfer. Membranes were blocked with $4 \%$ non-fat milk for $1 \mathrm{~h}$ at room temperature and then incubated with specific antibodies at $4^{\circ} \mathrm{C}$ overnight. Membranes were subsequently washed three times and incubated in horseradish peroxidase-coupled goat anti-rabbit IgG antibody for $3 \mathrm{~h}$ at room temperature. Immunoreactive bands were visualized by an enhanced chemiluminescence assay. Band intensities were measured by an MSF-300G Scanner (Microtek Laboratory).

Statistical analysis. Values are provided as the mean \pm SD. Statistical differences between mean values were determined using one-way ANOVA. $\mathrm{P}<0.05$ was considered to indicate a statistically significant difference.

\section{Results}

Effect of UII on TAM infiltration. To observe the effect of UII on TAM infiltration, immunohistochemical staining for CD68 antibody was measured. As shown in Fig. 1A, positive staining for CD68 was localized mainly in the cytoplasm. Few $\mathrm{CD}^{+} 8^{+}$TAMs were detected in the control group. A significant increase of CD68 ${ }^{+}$TAMs was observed in the UII group. Statistical analysis showed that compared with the control group, the integral optical density (IOD) of $\mathrm{CD}^{+} 8^{+}$immunostaining was significantly increased in the UII group $(\mathrm{P}<0.01$, Fig. 1B).

Effect of UII on the levels of TNF- $\alpha, I L-6$ and MMP-9. As presented in Fig. 2, the levels of IL-6, TNF- $\alpha$ and MMP-9 in the UII group increased significantly compared with the control group $(\mathrm{P}<0.05)$. This result shows that UII was capable of promoting the production of IL-6, TNF- $\alpha$ and MMP-9 in the tumor tissues. 
A
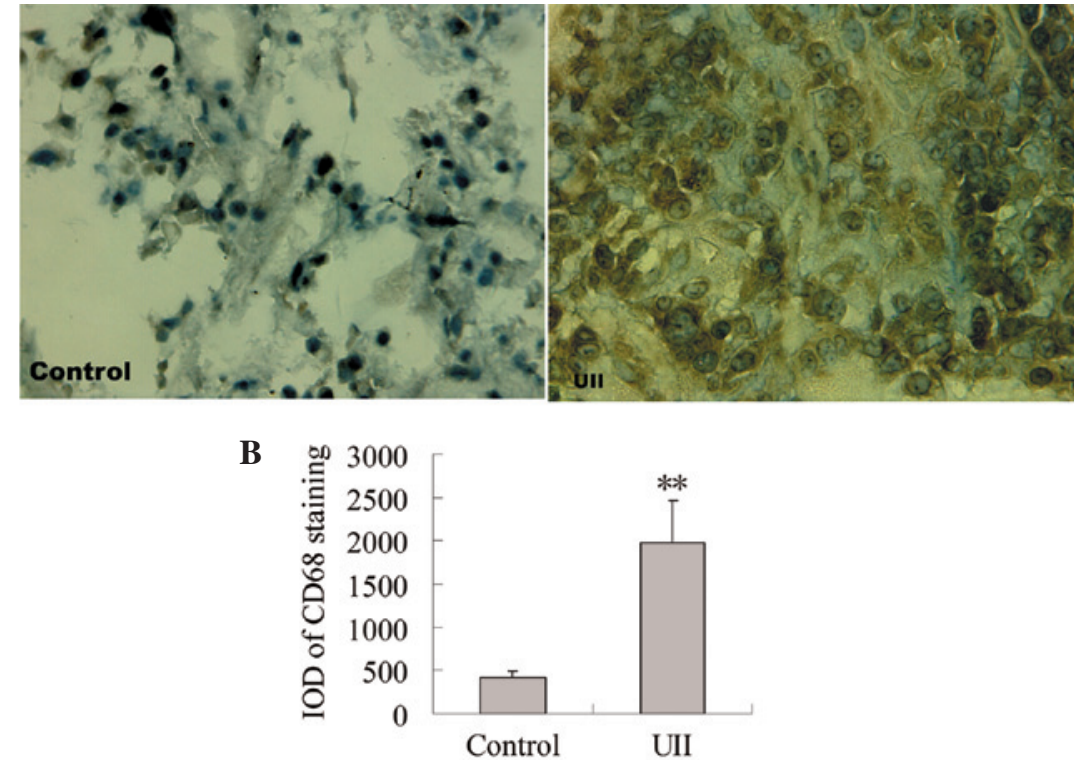

Figure 1. Effect of UII on TAM infiltration. Immunohistochemistry was carried out using CD68 antibody. Positive staining was indicated by brown deposits. (A) Representative photomicrographs showing immunohistochemical examination for CD68 staining in the control group and the UII group. (B) The IOD of CD68 immunostaining. Data are expressed as mean $\pm \mathrm{SD}(\mathrm{n}=6) .{ }^{* *} \mathrm{P}<0.01$ vs. control group. UII, urotensin II; TAMs, tumor-associated macrophages; IOD, integral optical density.

A

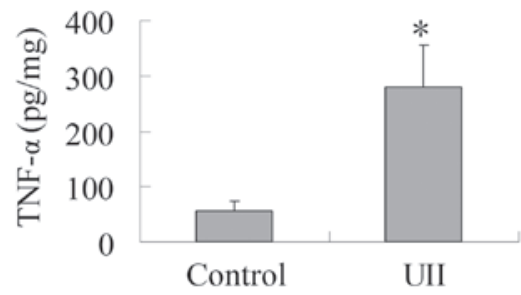

B

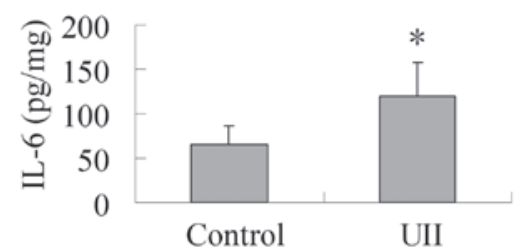

C

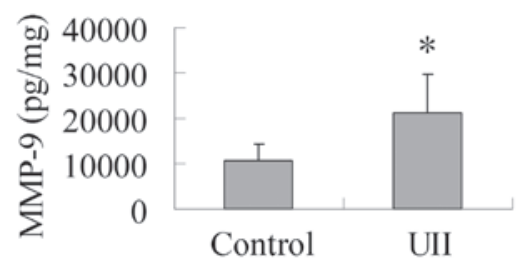

Figure 2. Effect of UII on the levels of TNF- $\alpha$, IL-6 and MMP-9. The tumor tissues were homogenized in lysis buffer (RIPA) containing PMSF at $4^{\circ} \mathrm{C}$. Homogenates were centrifuged at $12,000 \mathrm{x}$ g for $15 \mathrm{~min}$ at $4^{\circ} \mathrm{C}$, and supernatant fractions were used for ELISA analysis to determine the levels of TNF- $\alpha$, IL-6 and MMP-9. (A) Effect of UII on the level of TNF- $\alpha$. (B) Effect of UII on the level of IL-6. (C) Effect of UII on the level of MMP-9. The results are expressed as mean $\pm \mathrm{SD}(\mathrm{n}=6)$. ${ }^{*} \mathrm{P}<0.05$ vs. control group. UII, urotensin II; TNF- $\alpha$, tumor necrosis factor- $\alpha$; IL-6, interleukin-6; MMP-9, matrix metalloproteinase-9; PMSF, phenylmethanesulfonyl fluoride; ELISA, enzyme-linked immunosorbent assay.

Effect of UII on the expression of $p-N F-\kappa B$. As shown in Fig. 3, the expression of NF- $\mathrm{KB}$ between the control group and the UII group was not statistically different. When compared with the control group, UII increased the ratio of $\mathrm{p}-\mathrm{NF}-\mathrm{\kappa B} / \mathrm{NF}-\kappa \mathrm{B}$
A

Control UII

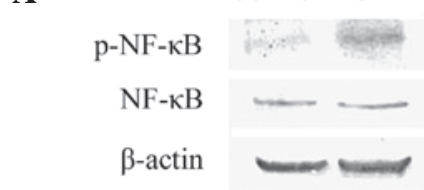

B

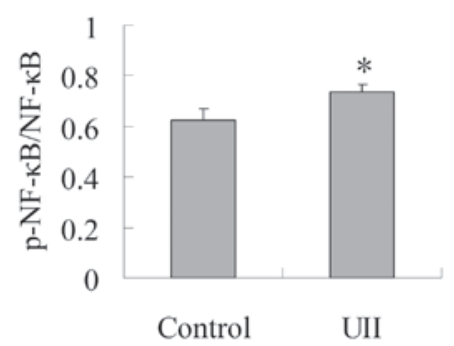

Figure 3. Effect of UII on the protein expression of p-NF-кB. The lysis supernatants were subjected to SDS-PAGE and analyzed by western blot analysis. (A) Representative blots are shown. (B) Band intensities were measured by an MSF-300G scanner and the ratio of p-NF- $\kappa$ B and NF- $\kappa$ B was calculated. The results are expressed as mean $\pm \mathrm{SD}(\mathrm{n}=6)$. ${ }^{*} \mathrm{P}<0.05$ vs. control group.

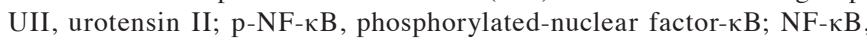
nuclear factor- $\mathrm{\kappa} \mathrm{B}$.

significantly $(\mathrm{P}<0.05)$, which suggests that UII was capable of promoting the activation of NF- $\mathrm{KB}$.

\section{Discussion}

The recent study in our laboratory showed that UII stimulates the proliferation of lung adenocarcinoma A549 cells and promotes lung adenocarcinoma growth in a nude mice xenograft model (27). In this study, we demonstrated that UII promotes the formation of lung adenocarcinoma inflammatory microenvironment in tumor-bearing nude mice and induces the activation of NF- $\mathrm{kB}$. These findings implied that modula- 
tion of lung adenocarcinoma inflammatory microenvironment by the NF- $\mathrm{NB}$ pathway may be one of the mechanisms whereby UII promotes lung adenocarcinoma growth.

Recent studies have shown that the tumor inflammatory microenvironment plays an important role in cancer progression. TAMs, in particular, have been found to be associated with tumor growth and metastasis (5-7). A large number of studies concerning numerous tumor types, including colorectal cancer (5), supraglottic laryngeal carcinoma (6), Ewing's sarcoma (7), intestinal type gastric cancer (29), pancreatic cancer (30), non-gynecologic leiomyosarcoma (31) and thyroid cancer (32), have shown that the presence of TAMs in the tumor microenvironment is associated with a worse prognosis. Therefore, TAMs play an important role in tumor progression. Usually, the pan-macrophage/monocyte marker CD68 is used as a marker for TAMs. In this study, we determined the number of infiltrating TAMs in tumor tissues by immunohistochemical staining of CD68. Our results showed that compared with the control group, the number of TAMs in the UII group markedly increased, suggesting that UII may contribute to the formation of the inflammatory microenvironment in lung adenocarcinoma.

The role of TAMs in the tumor microenvironment and tumor development is complex and multifaceted (33). TAMs release pro-angiogenic factors and cytokines, including MMP-9, vascular-endothelial growth factor (VEGF), plateletderived growth factor (PDGF) and TNF- $\alpha$. TAMs may promote tumor growth by releasing epidermal growth factor (EGF), IL-6 and PDGF. TAMs may also facilitate tumor cell invasion and metastasis by releasing MMPs (MMP-2 and MMP-9), which degrade the extracellular matrix and the basement membrane. These studies suggest that TAMs contribute to tumor progression by modulating the tumor inflammatory microenvironment. Our present study demonstrated that UII promoted the release of IL-6, which may be one of the causes of UII stimulation of lung adenocarcinoma growth. Consistent with our results, it has been shown that UII stimulates the release of IL-6 in cardiomyocytes (22). In addition, our study showed that the levels of TNF- $\alpha$ and MMP-9 in the UII group were higher than those of the control group, which has not been demonstrated until now. Our study suggests that UII may promote the release of inflammatory cytokines in the tumor microenvironment, contributing to angiogenesis, tumor growth and metastasis.

$\mathrm{NF}-\kappa \mathrm{B}$ is an important transcription factor for the expression of numerous pro-inflammatory genes including IL- 6 , TNF- $\alpha$ and MMP-9 (34). In the classic pathway, activation of $N F-\kappa B$, in particular the most abundant form (p50/p65 heterodimer), depends on the phosphorylation of its endogenous inhibitor (I- $\kappa \mathrm{B})$ primarily by I- $\kappa \mathrm{B}$ kinases (IKKs). This leads to ubiquitination and proteasomal degradation of $\mathrm{I}-\kappa \mathrm{B}$. The liberated $\mathrm{NF}-\kappa \mathrm{B}$ dimer then translocates to the nucleus, where it activates specific target genes. Growing evidence indicates post-translational modifications of $\mathrm{NF}-\kappa \mathrm{B}$, particularly phosphorylation and acetylation, also play significant roles in the activation of the transcription factor. In response to certain stimuli, the transactivation potential of $\mathrm{NF}-\kappa \mathrm{B}$ is regulated by phosphorylation of its p65 subunit at specific serine residues (35). Our present study showed that compared with the control group, the expression of $\mathrm{p}-\mathrm{NF}-\kappa \mathrm{B}$ in the UII group was significantly higher. This was in accordance with the levels of IL-6, TNF- $\alpha$ and MMP-9, suggesting that the upregulated levels of IL-6, TNF- $\alpha$ and MMP-9 may have resulted from enhanced activation of NF- $\kappa$ B.

In conclusion, our present study demonstrated that UII increased the infiltration of CD68 ${ }^{+}$TAMs in lung adenocarcinoma tissues. The enhanced levels of IL-6, TNF- $\alpha$ and MMP-9 in the tumor microenvironment induced by UII (speculated to be due to the increased activation of $N F-\kappa B$ ) may be one of the important mechanisms by which UII promotes lung adenocarcinoma growth. These findings imply that antagonists of UII or UT-R have a potential in the prevention and treatment of lung adenocarcinoma.

\section{Acknowledgements}

This study was supported by the National Natural Science Foundation of China (81001431, 81171013 and 81070889), the Key Subject of College and Universities Natural Science Foundation of Jiangsu Province (10KJA320052), the Natural Science Foundation of Jiangsu Higher Education Institutions of China (11KJB310014), the Xuzhou Scientific and Technological Project (xzzd1052) and the Priority Academic Program Development of Jiangsu Higher Education Institutions.

\section{References}

1. Balkwill $\mathrm{F}$ and Mantovani A: Inflammation and cancer: back to Virchow? Lancet 357: 539-545, 2001.

2. Gonda TA, Tu S and Wang TC: Chronic inflammation, the tumor microenvironment and carcinogenesis. Cell Cycle 8: 2005-2013, 2009.

3. Marx J: Cancer research. Inflammation and cancer: the link grows stronger. Science 306: 966-968, 2004.

4. Coussens LM and Werb Z: Inflammation and cancer. Nature 420: 860-867, 2002.

5. Kang JC, Chen JS, Lee CH, Chang JJ and Shieh YS: Intratumoral macrophage counts correlate with tumor progression in colorectal cancer. J Surg Oncol 102: 242-248, 2010.

6. Lin JY, Li XY, Tadashi N and Dong P: Clinical significance of tumor-associated macrophage infiltration in supraglottic laryngeal carcinoma. Chin J Cancer 30: 280-286, 2011.

7. Fujiwara T, Fukushi J, Yamamoto S, et al: Macrophage infiltration predicts a poor prognosis for human ewing sarcoma. Am J Pathol 179: 1157-1170, 2011

8. Lu H, Ouyang W and Huang C: Inflammation, a key event in cancer development. Mol Cancer Res 4: 221-233, 2006.

9. Cho WC, Kwan CK, Yau S, So PP, Poon PC and Au JS: The role of inflammation in the pathogenesis of lung cancer. Expert Opin Ther Targets 15: 1127-1137, 2011.

10. O'Callaghan DS, O'Donnell D, O'Connell F and O'Byrne KJ: The role of inflammation in the pathogenesis of non-small cell lung cancer. J Thorac Oncol 5: 2024-2036, 2010.

11. Lee G, Walser TC and Dubinett SM: Chronic inflammation, chronic obstructive pulmonary disease, and lung cancer. Curr Opin Pulm Med 15: 303-307, 2009.

12. Walser T, Cui X, Yanagawa J, et al: Smoking and lung cancer: the role of inflammation. Proc Am Thorac Soc 5: 811-815, 2008.

13. Takahashi H, Ogata H, Nishigaki R, Broide DH and Karin M: Tobacco smoke promotes lung tumorigenesis by triggering IKKbetaand JNK1-dependent inflammation. Cancer Cell 17: 89-97, 2010.

14. Slatore CG, Au DH, Littman AJ, Satia JA and White E: Association of nonsteroidal anti-inflammatory drugs with lung cancer: results from a large cohort study. Cancer Epidemiol Biomarkers Prev 18: 1203-1207, 2009.

15. Akhmedkhanov A, Toniolo P, Zeleniuch-Jacquotte A, Koenig KL and Shore RE: Aspirin and lung cancer in women. Br J Cancer 87: 49-53, 2002.

16. Pearson D, Shively JE, Clark BR, et al: Urotensin II: a somatostatin-like peptide in the caudal neurosecretory system of fishes. Proc Natl Acad Sci USA 77: 5021-5024, 1980. 
17. Coulouarn Y, Lihrmann I, Jegou S, et al: Cloning of the cDNA encoding the urotensin II precursor in frog and human reveals intense expression of the urotensin II gene in motoneurons of the spinal cord. Proc Natl Acad Sci USA 95: 15803-15808, 1998.

18. Elshourbagy NA, Douglas SA, Shabon U, et al: Molecular and pharmacological characterization of genes encoding urotensin-II peptides and their cognate $\mathrm{G}$-protein-coupled receptors from the mouse and monkey. Br J Pharmacol 136: 9-22, 2002.

19. Coulouarn Y, Jégou S, Tostivint H, Vaudry H and Lihrmann I: Cloning, sequence analysis and tissue distribution of the mouse and rat urotensin II precursors. FEBS Lett 457: 28-32, 1999.

20. Ames RS, Sarau HM, Chambers JK, et al: Human urotensin-II is a potent vasoconstrictor and agonist for the orphan receptor GPR14. Nature 401: 282-286, 1999.

21. Davenport AP and Maguire JJ: Urotensin II: fish neuropeptide catches orphan receptor. Trends Pharmacol Sci 21: 80-82, 2000.

22. Johns DG, Ao Z, Naselsky D, et al: Urotensin-II-mediated cardiomyocyte hypertrophy: effect of receptor antagonism and role of inflammatory mediators. Naunyn Schmiedebergs Arch Pharmacol 370: 238-250, 2004.

23. Segain JP, Rolli-Derkinderen M, Gervois N, Raingeard de la Blétière D, Loirand G and Pacaud P: Urotensin II is a new chemotactic factor for UT receptor-expressing monocytes. J Immunol 179: 901-909, 2007.

24. Cirillo P, De Rosa S, Pacileo M, et al: Human urotensin II induces tissue factor and cellular adhesion molecules expression in human coronary endothelial cells: an emerging role for urotensin II in cardiovascular disease. J Thromb Haemost 6 : 726-736, 2008

25. Bousette N, Patel L, Douglas SA, Ohlstein EH and Giaid A: Increased expression of urotensin II and its cognate receptor GPR14 in atherosclerotic lesions of the human aorta. Atherosclerosis 176: 117-123, 2004.

26. Birker-Robaczewska M, Boukhadra C, Studer R, Mueller C, Binkert $\mathrm{C}$ and Nayler O: The expression of urotensin II receptor (U2R) is up-regulated by interferon-gamma. J Recept Signal Transduct Res 23: 289-305, 2003.
27. Wu YQ, Song Z, Zhou CH, Xing SH, Pei DS and Zheng JN: Expression of urotensin II and its receptor in human lung adenocarcinoma A549 cells and the effect of urotensin II on lung adenocarcinoma growth in vitro and in vivo. Oncol Rep 24: 1179-1184, 2010.

28. Shi J, Zheng D, Liu Y, Sham MH, Tam P, Farzaneh F and Xu R: Overexpression of soluble TRAIL induces apoptosis in human lung adenocarcinoma and inhibits growth of tumor xenografts in nude mice. Cancer Res 65: 1687-1692, 2005.

29. Kawahara A, Hattori S, Akiba J, et al: Infiltration of thymidine phosphorylase-positive macrophages is closely associated with tumor angiogenesis and survival in intestinal type gastric cancer. Oncol Rep 24: 405-415, 2010.

30. Kurahara H, Shinchi H, Mataki Y, et al: Significance of M2-polarized tumor-associated macrophage in pancreatic cancer. J Surg Res 167: e211-219, 2009.

31. Lee CH, Espinosa I, Vrijaldenhoven S, et al: Prognostic significance of macrophage infiltration in leiomyosarcomas. Clin Cancer Res 14: 1423-1430, 2008.

32. Ryder M, Ghossein RA, Ricarte-Filho JC, Knauf JA and Fagin JA: Increased density of tumor-associated macrophages is associated with decreased survival in advanced thyroid cancer. Endocr Relat Cancer 15: 1069-1074, 2008.

33. Sica A: Role of tumour-associated macrophages in cancer-related inflammation. Exp Oncol 32: 153-158, 2010.

34. Aggarwal BB, Shishodia S, Sandur SK, Pandey MK and Sethi G: Inflammation and cancer: how hot is the link? Biochem Pharmacol 72: 1605-1621, 2006.

35. Sun J, Ramnath RD, Zhi L, Tamizhselvi R and Bhatia M: Substance $P$ enhances NF-kappaB transactivation and chemokine response in murine macrophages via ERK1/2 and p38 MAPK signaling pathways. Am J Physiol Cell Physiol 294: C1586-1596, 2008 . 